\title{
MANAJEMEN PENGELOLAAN BARANG MILIK DAERAH MENUJU OPINI WAJAR TANPA PENGECUALIAN (WTP) (Studi Kasus pada Pemerintahan di Kabupaten Provinsi Kalimantan Barat)
}

\author{
Management of Regional Property Management Towards Unqualified Opinion \\ (Case Study on District Government in West Kalimantan)
}

\author{
Reiza Apriadinihari ${ }^{*}$, Haryono ${ }^{* *}$, Nina Febriana Dosinta ${ }^{* *}$ \\ Badan Pemeriksa Keuangan Perwakilan Provinsi Kalimantan Barat
}

\begin{abstract}
This study aims to understand the process of managing Regional Property (BMD) in district governments that have not yet obtained an Unqualified Opinion in audits conducted by the Supreme Audit Board (BPK) and to analyze the causes of regional property management problems. This research is a qualitative case study research with data collection techniques through observation, interviews, and documentation studies. The results showed that in the management of the regional property, the local government had carried out in accordance with statutory provisions, namely the Regulation of the Minister of Home Affairs Number 19 of 2016 concerning Guidelines for the Management of Regional Property. From the research results also obtained the results of the analysis of the causes of regional property management problems in the district government, namely in human resources. In addition, the lack of coordination between related work units, the inadequate inventory process and inadequate documentation are also the problems found in this study.
\end{abstract}

Keywords: Regional Property Management, Opinion of Supreme Audit Board of the Republic of Indonesia.

\section{PENDAHULUAN}

Pemberian opini audit oleh Badan Pemeriksa Keuangan (BPK) dimaksudkan untuk memberikan penilaian atas kewajaran laporan keuangan pemerintah. Selain itu, pemberian opini audit ini diharapkan dapat meningkatkan kepercayaan pengguna laporan keuangan pemerintah atas informasi yang disajikan dalam laporan tersebut. Salah satu yang mempengaruhi opini audit BPK atas laporan keuangan pemerintah baik pada Pemerintah Pusat, Kementerian/Lembaga maupun pada pemerintah daerah adalah tentang aset tetap. Aset tetap merupakan faktor penting dalam pengelolaan keuangan negara maupun daerah. Ini tercermin dalam laporan keuangan pemerintah, dimana nilai aset tetapnya memiliki nilai paling besar dibanding komponen lain.

Aset daerah memiliki peranan penting bagi pemerintah daerah sehingga memerlukan pengelolaan yang benar karena merupakan salah satu indikator dalam penerapan sistem akuntansi berbasis akrual, yaitu dengan penyajian laporan aset yang akuntabel dalam Laporan Keuangan Pemerintah Daerah (LKPD).

Keberadaan aset tetap ini juga mempengaruhi kelancaran roda penyelenggaraan pemerintahan dan pembangunan. Tidak tertibnya penatausahaan dan pengelolaan aset tetap menjadi salah satu penyebabnya. Permasalahan aset tetap dapat mempengaruhi opini apabila ada kondisi terjadi 
pembatasan lingkup audit atau kecukupan bukti. Kondisi lainnya adalah terjadinya penyimpangan dari prinsip akuntansi atau salah saji. Kondisi ini harus dikaitkan dengan tingkat materialitas akun aset tetap dan dampaknya terhadap laporan keuangan secara keseluruhan. Pembenahan tata kelola aset daerah ke arah yang tertib dan akuntabel menjadi hal yang substansial ditengah usaha pemerintah daerah untuk meningkatkan citra pengelolaan keuangan daerah yang baik melalui Laporan Keuangan Pemerintah Daerah (LKPD) yang Wajar Tanpa Pengecualian (Unqualified Opinion).

Penelitian yang meneliti tentang permasalahan aset, seperti yang dilakukan oleh Syahputra, Syaukat dan Irwanto (2018) menyatakan bahwa lemahnya kompetensi SDM pengelola BMD tidak terlepas dari kurang optimalnya pembinaan, pengawasan dan pengendalian pada pengurus BMD dan ini juga berdampak pada kinerja aparatur pengelola BMD. Strategi prioritas yang tepat untuk diimplementasikan yaitu peningkatan kualitas SDM pengurus BMD dalam mengelola dan menyusun laporan BMD.

Penelitian yang dilakukan oleh Mulyani, Rachmina dan Kusnadi (2016) menyimpulkan bahwa Sistem pengelolaan aset tetap belum diimplementasikan secara optimal. Hal ini mempengaruhi kinerja pengelolaan aset. Indek kinerja tanah terendah pada pemenuhan aspek yuridis, sedangkan pada Gedung/Bangunan indek terendah pada pemenuhan aspek fisik. Sedangkan menurut persepsi para ahli pengelolaan aset permasalahan terbesar menyangkut aspek fisik. Faktor internal dan eksternal yang paling berpengaruh dalam pengelolaan aset tetap secara berurutan adalah kekuatan, peluang, ancaman dan kelemahan. Namun secara umum pengelolaan aset tetap memiliki peluang yang sangat tinggi dan kekuatan yang sangat besar untuk dapat dimanfaatkan bagi perbaikan pengelolaan aset tetap. Oleh karena itu, tujuan dalam penelitian ini adalah untuk mengetahui sejauh mana penerapan perencanaan, pelaksanaan, penatausahaan dan pengawasan sesuai dengan ketentuan perundang-undangan dalam pengelolaan barang milik daerah; serta faktor penghambat penyelesaian pengelolaan BMD.

\section{TINJAUAN PUSTAKA}

Freeman (2003:322) menyatakan bahwa pemerintah banyak menggunakan aset jangka panjang dalam operasinya, seperti : tanah, bangunan dan peralatan. Aset tersebut memiliki substansi fisik dan diharapkan dapat memberikan pelayanan untuk waktu lebih dari satu tahun, meskipun masa manfaatnya akan menurun sesuai umur ekonomisnya. Aset tetap pemerintah diperoleh dari pembelian, sewa guna usaha, pemberian, sitaan, kekuasaan pemerintah untuk merebut properti dan memberikan kompensasi kepada pemilik untuk kepentingan umum, serta pengembalian properti yang tidak diketahui pemiliknya kepada pemerintah.

Aset tetap merupakan aset berwujud yang diperoleh dalam bentuk siap pakai atau yang harus dibangun terlebih dahulu, yang memiliki umur ekonomis lebih dari 1 (satu) tahun yang dimaksudkan untuk dipergunakan dalam aktivitas pemerintahan atau untuk dipergunakan secara langsung oleh masyarakat secara umum. Aset memiliki wujud, sehingga sering kali aset tetap disebut dengan aset tetap berwujud (tangible fixed assets). Aset tetap pemerintah mencakup tanah, gedung dan bangunan, peralatan dan mesin, jalan, irigasi dan jaringan, konstruksi dalam pengerjaan, serta aset tetap lainnya (Tanjung, 2012:53-54).

Menurut Lukman dan Akbar (2010) konsep pengelolaan aset pertama kali dicetuskan oleh industri privat. Penerapan konsep pengelolaan aset telah terbukti memberikan hasil positif dan menghasilkan keuntungan yang signifikan bagi perusahaan sektor privat. Kesuksesan sektor privat ini mulai dilirik oleh aparatur pemerintah dan perusahaan-perusahaan publik. Oleh karena itu, konsep 
pengelolaan aset mulai dikenali sebagai suatu cara yang dapat diterapkan oleh pemerintah dalam mengelola aset-aset yang dimiliki. Surminah (2008) menyatakan bahwa pengelolaan aset adalah suatu sistem penatalaksanaan atau suatu unit fungsional yang berfungsi untuk mengoperasikan seperangkat sumber daya (sumber daya manusia, uang, mesin, barang, waktu) dan seperangkat instrument (metoda, standar/kriteria) untuk mencapai satu tujuan. Kebutuhan akan pengelolaan aset menjadi penting yang berhubungan dengan ketersediaan, efisiensi, mutu, kesinambungan perusahaan dan pemenuhan keselamatan lingkungan) aset fisik yang dimiliki perusahaan.

Menurut Sholeh dan Rochmansjah (2010) sasaran strategis yang harus dicapai dalam kebijakan pengelolaan aset/barang milik daerah antara lain:

a) Terwujudnya ketertiban administrasi mengenai kekayaan daerah;

b) Terciptanya efisiensi dan efektivitas penggunaan aset daerah;

c) Pengamanan aset daerah;

d) Tersedianya data/informasi yang akurat mengenai jumlah kekayaan daerah.

Lebih lanjut Sholeh dan Rochmansjah (2010) menjelaskan strategi optimalisasi pengelolaan barang milik daerah meliputi :

a) Identifikasi dan inventarisasi nilai dan potensi aset daerah.

b) Adanya sistem informasi manajemen aset daerah.

c) Melibatkan berbagai profesi atau keahlian yang terkait seperti auditor internal dan appraisal (penilai).

d) Pengawasan dan pengendalian pemanfaatan aset.

Menurut Peraturan Pemerintah (PP) Nomor 27 Tahun 2014 tentang Pengelolaan Barang Milik Negara/Daerah dan Peraturan Menteri Dalam Negeri (Permendagri) Nomor 19 Tahun 2016 tentang Pedoman Pengelolaan Barang Milik Daerah, pengelolaan barang milik daerah meliputi kegiatankegiatan sebagai berikut:

a. Perencanaan kebutuhan dan penganggaran

b. Pengadaan

c. Penggunaan

d. Pemanfaatan

e. Pengamanan dan pemeliharaan

f. Penilaian

g. Pemindahtangan

h. Pemusnahan

i. Penghapusan

j. Penatausahaan

k. Pembinaan, pengawasan dan pengendalian.

\section{METODE PENELITIAN}

Rancangan penelitian ini adalah metode kualitatif dengan pendekatan studi kasus. Penelitian ini bertujuan untuk mendapatkan pemahaman yang mendalam mengenai faktor-faktor yang mempengaruhi manajemen barang milik daerah dalam rangka peningkatan opini laporan keuangan pada Pemerintah Kabupaten yang belum memperoleh opini WTP dengan berdasarkan peraturan mengenai pengelolaan barang milik daerah. Menurut Gunawan (2013), penelitian kualitatif adalah penelitian yang bertujuan untuk mendapatkan pemahaman yang mendalam tentang manusia dan sosial, bukan mendeskripsikan bagian permukaan dari suatu realitas sebagaimana dilakukan penelitian kuantitatif dengan positivismenya. Penelitian dilakukan dalam latar (setting) yang alamiah (naturalistic) bukan hasil perlakuan (treatment) atau manipulasi variabel yang dilibatkan". 
Penelitian ini dilakukan dengan melakukan analisis secara kronologis berdasarkan temuantemuan yang terdapat dalam laporan hasil pemeriksaan BPK RI yang dikaitkan dengan Peraturan Menteri Dalam Negeri (Permendagri) Nomor 19 Tahun 2016 tentang Pedoman Pengelolaan Barang Milik Daerah.

Teknik pengumpulan data yang ditempuh dalam penelitian ini adalah melalui wawancara mendalam (indepth interview), dan dokumentasi (documentation). Wawancara dilakukan kepada pihak-pihak yang terkait dengan proses pengelolaan barang milik daerah, yaitu Sekretaris Daerah selaku pengelola barang, Kepala SKPD selaku pengguna barang, Kepala Bidang Aset dan pengurus barang. Analisis data dilakukan bersamaan dengan proses pengumpulan data. Teknik analisis data dalam penelitian ini dilakukan dengan tiga tahapan sesuai dengan yang dikemukakan oleh Miles dan Huberman (dalam Gunawan 2013), yaitu:
a. Reduksi Data;
b. Paparan Data;
c. Penarikan Kesimpulan dan Verifikasi.

\section{HASIL DAN PEMBAHASAN}

\subsection{Penerapan Perencanaan, Pelaksanaan, Penatausahaan dan Pengawasan Sesuai Dengan Ketentuan Perundang-Undangan dalam Pengelolaan Barang Milik \\ Daerah}

Dalam rangka menganalisis permasalahan mengenai pengelolaan BMD, telah dilakukan pengumpulan informasi berupa temuan mengenai pengelolaan aset tetap dari Laporan Hasil Pemeriksaan (LHP) Badan Pemeriksa Keuangan periode tahun 2017-2018. Dari informasi tersebut, peneliti kemudian melakukan wawancara kepada informan yang terdiri dari Sekretaris Daerah selaku Pengelola Barang, Kepala Bidang Aset Daerah serta Pengurus Barang Pengguna pada Pemerintah Kabupaten yang sampai dengan tahun pemeriksaan LKPD 2018 (LKPD TA 2017) belum memperoleh opini WTP.

Tabel 4.4. Kodifikasi Informan Penelitian

\begin{tabular}{lccc}
\hline \multicolumn{1}{c}{ Entitas } & Pengelola Barang & Kepala Bidang Aset & Pengurus Barang \\
\hline Kabupaten I & I.1. & I.2. & I.7. s.d. I.16. \\
\hline Kabupaten II & I.3. & I.4. & I.17. s.d. I.26. \\
\hline Kabupaten III & I.5. & I.6. & I.27. s.d. I.36. \\
\hline
\end{tabular}

Wawancara tersebut bertujuan untuk memperoleh informasi mengenai proses bisnis dari pengelolaan aset tetap di wilayah kabupaten tersebut. Proses bisnis tersebut mencakup seluruh kegiatan dalam pengelolaan barang milik daerah menurut Permendagri Nomor 19 Tahun 2016 yang meliputi perencanaan kebutuhan dan penganggaran, pengadaan, penggunaan, pemanfaatan, pengamanan dan pemeliharaan, penilaian, pemindahtanganan, pemusnahan, penghapusan, penatausahaan dan pembinaan, pengawasan dan pengendalian. Dari wawancara tersebut juga dilakukan analisis mengenai kendala dan penyebab terjadinya kendala tersebut.

\subsubsection{Perencanaan}

Perencanaan dilakukan agar BMD dapat dimanfaatkan dengan prinsip efektif dan efisien sesuai dengan kebutuhan pelaksanaan tugas dan fungsi dari Organisasi Perangkat Daerah (OPD) terkait. Proses perencanaan dimulai dari masing-masing Pengguna Barang/Kuasa yang mengusulkan Rencana Kerja Barang Milik Daerah (RKBMD) untuk kemudian dilakukan penelaahan oleh Pengelola Barang. Hasil telaahan tersebut nantinya akan digunakan sebagai dasar dalam penyusunan rencana kerja dan anggaran OPD. 
Proses perencanaan pada Pemda telah sesuai dengan Permendagri Nomor 19/2016 dimana OPD diwajibkan melakukan penyusunan atas RKBMD sebagai dasar penyusunan rencana kerja dan anggaran. Namun perencanaan tersebut hanya meliputi perencanaan pengadaan dan perencanaan pemeliharaan, belum mencakup perencanaan pemanfaatan, perencanaan pemindahtanganan serta perencanaan penghapusan sebagaimana yang termuat dalam Permendagri Nomor 19/2016. Seperti yang disampaikan oleh Informan I.6 berikut:

"Penyusunan perencanaan cuma untuk pengadaan sama pemeliharaan saja, karena untuk pemanfaatan saya rasa sudah dipertimbangkan masing-masing oleh kepala OPD dalam mengusulkan pengadaan tersebut. Kalau untuk penghapusan karna kita belum pernah melakukan penghapusan untuk barang-barang yang rusak atau tidak digunakan lagi."

Permasalahan mengenai proses Perencanaan yang berpengaruh terhadap pengelolaan BMD yang ada dalam Laporan Hasil Pemeriksaan BPK RI antara lain Terdapat BMD berupa bangunan yang tidak segera dimanfaatkan karena berbagai perencanaan yang tidak memadai serta terdapat BMD yang dipergunakan oleh pihak ketiga, namun biaya pemeliharaannya ditanggung oleh Pemda.

\subsubsection{Pelaksanaan}

1) Pengadaan

Proses pengadaan barang milik daerah dilaksanakan oleh panitia pengadaan di tiap-tiap OPD atau SKPD melalui ULP (Unit Layanan Pengadaan) dengan menggunakan LPSE (Layanan Pengadaan Barang Dan Jasa Secara Elektronik). Panitia pengadaan ditetapkan dengan Surat Keputusan kepala daerah dengan mengikuti mekanisme yang ditetapkan dalam aturan pengadaan. Berdasarkan analisis hasil penelitian menunjukkan bahwa proses pengadaan sudah dilaksanakan sesuai dengan aturan, karena sudah dilaksanakan oleh panitia pengadaan barang/jasa melalui ULP. Atas hasil pengadaan tersebut kemudian pengurus barang melakukan penginputan data pengadaan barang ke dalam aplikasi pengelolaan barang.

2) Penggunaan dan Pemanfaatan

Penggunaan BMD merupakan kegiatan yang dilakukan oleh Pengguna Barang dalam mengelola dan menatausahakan BMD untuk menunjang tugas pokok dan fungsi pada OPD yang bersangkutan berdasarkan keputusan penetapan status penggunaan BMD oleh Kepala Daerah setiap tahunnya. Status penggunaan barang milik daerah pada masing-masing OPD ditetapkan dalam rangka tertib pengelolaan barang milik daerah dan kepastian hak, wewenang dan tanggung jawab kepala OPD.

Dalam pelaksanaannya belum semua BMD telah ditetapkan status penggunaannya. Terdapat juga BMD yang digunakan oleh pihak-pihak tidak sesuai ketentuan seperti misalnya oleh pegawai yang sudah pensiun atau sudah mutasi ke Pemda lainnya seperti yang disampaikan oleh informan I.6 berikut ini:

"Banyak BMD yang dipakai oleh pegawai atau pejabat yang sudah pensiun, ada juga yang pindah ke Pemda lain namun kendaraannya belum dibalikkan ke Pemda. Kami kesulitan karna informasi dari OPD tidak lengkap. Pengurus barang OPD juga biasanya tidak tahu pegawai mana yang bawa kendaraan yang mana karena kejadiannya sudah lama. Pengurus barang ini kan biasanya tiap tahun ganti."

Selain itu ada BMD yang digunakan oleh pegawai namun tidak disertakan dokumen pendukung dan tidak dilaporkan ke pengurus barang sehingga pada saat dilakukan pemeriksaan, pengurus barang tidak mengetahui keberadaan barang tersebut, hal ini dijelaskan oleh Informan I.2:

"Setelah proses pengadaan, barang-barang ini kemudian diserahkan ke bagian-bagian.

Nah, dari bagian-bagian itu nyerahkan ke pegawai tapi tidak dibuatkan BAST nya. Kepala 
OPD nya juga tidak pernah memantau, jadinya pas pemeriksaan pengurus barang kebanyakan tidak tahu letak barang itu."

Permasalahan mengenai proses Penggunaan yang berpengaruh terhadap pengelolaan BMD yang tidak sesuai dengan ketentuan Permendagri Nomor 19/2016 seperti yang tercantum dalam Laporan Hasil Pemeriksaan BPK RI antara lain Penggunaan aset peralatan dan mesin oleh pegawai yang telah mutasi ke SKPD lain di lingkungan Pemda tidak sesuai ketentuan serta terdapat penggunaan aset oleh pegawai yang tidak didukung dengan surat penunjukan serta BAST penggunaan maupun dokumen izin penggunaan.

Pemanfaatan adalah pendayagunaan barang daerah yang tidak dipergunakan sesuai dengan tugas pokok dan fungsi satuan kerja perangkat daerah, dalam bentuk sewa, pinjam pakai, kerjasama pemanfaatan, dan bangun serah guna/bangun guna serah dengan tidak mengubah status kepemilikan.

Hasil wawancara kepada Pengelola Barang diketahui terdapat pemanfaatan BMD oleh pihak ketiga, seperti dijelaskan Informan I.3 sebagai berikut:

"Aset kami yang digunakan oleh pihak ketiga berupa kendaraan, tanah maupun bangunan. Pihak ketiga ini instansi vertikal seperti KPU, PDAM, kepolisian, kejaksaan. Pinjamnya bentuknya ada yang kerjasama ada juga yang pinjam pakai. Itu semua melalui persetujuan kepala daerah.

Menanggapi atas temuan oleh BPK RI mengenai pemanfaatan yang tidak sesuai ketentuan, diperoleh keterangan dari I.5 sebagai berikut:

"kelemahan kami memang dalam masalah dokumentasi. Kedepan kami akan mendata kembali BMD yang dipinjampakaikan kepada pihak luar, baik yang sudah habis masa pinjamnya maupun yang belum dibuatkan perjanjiannya, dan akan buatkan perjanjian sesuai ketentuan."

Permasalahan mengenai proses Pemanfaatan yang tidak sesuai dengan ketentuan Permendagri Nomor 19/2016 dan berpengaruh terhadap pengelolaan BMD seperti yang tercantum dalam Laporan Hasil Pemeriksaan BPK RI antara lain terdapat unit kendaraan yang dipinjam pakai oleh instansi pemerintah vertikal dan horizontal namun belum didukung dengan bukti perjanjian pinjam pakai oleh Pemerintah Kabupaten d.h.i Bupati atau Pengelola Barang dengan pihak peminjam pakai. Selain itu terdapat kendaraan bermotor yang dipinjampakaikan kepada pihak ketiga dan bukan merupakan bagian dari instansi pemerintahan baik pemerintah pusat maupun pemerintah daerah sehingga seharusnya tidak dapat menggunakan kendaraan bermotor tersebut melalui mekanisme pinjam pakai.

3) Pengamanan dan Pemeliharaan

Pengamanan BMD merupakan salah satu bentuk kegiatan pengelolaan BMD. Pengamanan tersebut meliputi pengamanan secara fisik, hukum dan administratif. Pengamanan secara fisik dilakukan dengan cara memasang tanda kepemilikan dan melakukan penjagaan. Pengamanan secara administrasi diantaranya dilakukan dengan cara menyimpan bukti kepemilikan aset tetap. Pengamanan secara hukum dilakukan dengan cara melakukan sertifikasi atas tanah milik pemerintah daerah dan atas aset Kendaraan Bermotor dilakukan dengan menyimpan Bukti Kepemilikan Kendaraan Bermotor oleh Pengelola Barang.

Hasil penelitian mengenai proses pengamanan BMD oleh Pemda diperoleh informasi antara lain dinyatakan oleh I.2. sebagai berikut:

"untuk pengamanan BMD sudah diupayakan oleh Pemda yaitu untuk aset tanah telah bersertifikat Hak Pakai serta SPT/ SKT. Namun ada juga beberapa yang tidak memiliki bukti kepemilikan. Ada yang hilang ada juga yang memang belum dibuat sertifikatnya. 
Untuk mengurus sertifikat itu perlu biaya jadi harus dianggarkan dulu, harus diukur dulu jadinya tidak bisa secara keseluruhan. Kalau untuk kendaraan bentuk pengamanan dokumennya pasti berupa STNK dan BPKB."

Sedangkan untuk pengamanan fisik diperoleh informasi dari informan I.4 sebagai berikut:

"Pengamanan fisik tanah kami menggunakan patok ataupun papan nama. Kalau gedung seharusnya dipagar yaa, tapi liat kemampuan pemda juga sehingga tidak semua aset dilakukan pengamanan seperti itu."

4) Penilaian

Penilaian BMD dilakukan dalam rangka penyusunan Neraca Pemerintah Daerah, pemanfaatan dan pemindahtanganan BMD. Penetapan nilai BMD dalam rangka penyusunan Neraca Pemerintah Daerah dilakukan dengan berpedoman pada Standar Akuntansi Pemerintahan (SAP). Penilaian BMD berupa tanah dan/atau bangunan dilaksanakan untuk mendapatkan nilai wajar dengan estimasi terendah menggunakan Nilai Jual Objek Pajak (NJOP).

Proses penilaian di masing-masing Pemda berbeda, dan untuk jenis barang juga berbeda, sesuai dengan keperluan, kondisi ini disampaikan oleh masing-masing Kepala Bidang Aset berikut ini, informasi I.2 menyatakan seperti berikut:

"Penilaian dilakukan oleh KPKNL untuk memperoleh nilai wajar, biasanya kami melakukan penilaian untuk barang-barang yang akan dilelang. Selain itu untuk aset yang belum ada nilainya (bernilai Rp0,00 atau Rp1,00) juga kami serahkan ke KPKNL untuk dilakukan penilaian."

5) Penghapusan

Penghapusan BMD meliputi:

a) Penghapusan dari Daftar Barang Pengguna dan/atau Kuasa Pengguna, yaitu penghapusan BMD yang dilakukan dalam hal BMD dimaksud sudah tidak berada dalam penguasaan pengguna dan/atau kuasa pengguna barang;

b) Penghapusan dari Daftar BMD, yaitu penghapusan BMD yang dilakukan dalam hal BMD dimaksud sudah beralih kepemilikan, terjadi pemusnahan atau karena sebab-sebab lain.

Pelaksanaan pemusnahan dituangkan dalam Berita Acara Pemusnahan dan dilaporkan kepada Kepala Daerah. Dalam pelaksanaannya, masih terdapat Pemda yang belum melakukan proses penghapusan. Informasi tambahan dari I.4 sebagai berikut:

"Disini belum melakukan penghapusan atas aset rusak, kami belum ada tim verifikasinya.

Tapi aset yang rusak sudah kami pindahkan ke (akun) aset lainnya, berdasar usulan OPD."

Permasalahan mengenai proses Penghapusan yang tidak sesuai dengan ketentuan Permendagri Nomor 19/2016 dan berpengaruh terhadap pengelolaan BMD seperti yang tercantum dalam Laporan Hasil Pemeriksaan BPK RI antara lain:

a) Terdapat BMD dalam keadaan rusak berat belum diusulkan maupun yang sudah diusulkan untuk dihapuskan. Proses penelitian dan verifikasi untuk menentukan kelayakan kondisi penggunaan tidak pernah dilakukan. 
b) Aset peralatan dan mesin yang hilang belum dilakukan permohonan penghapusan. Atas kasus kehilangan tersebut, belum mengajukan permohonan penghapusan maupun upaya tuntutan ganti rugi, dan masih mencatat sebagai aset pemda pada neraca.

6) Pemindahtanganan

Pemindahtanganan adalah pengalihan kepemilikan BMD sebagai tindak lanjut dari penghapusan dengan cara dijual, dipertukarkan, dihibahkan atau disertakan sebagai modal pemerintah.

Bentuk Pemindahtanganan meliputi penjualan, tukar-menukar, hibah maupun penyertaan modal. Proses pemindahtanganan di pemda dapat diperoleh informasi dari informan I.2:

"kalau pemindahtanganan di pemda kami bentuknya ada yang di lelang (penjualan) ada juga yang di hibah kan, biasanya hibah ke desa."

Mengenai temuan masih terdapat pencatatan aset yang telah diserahkan ke masyarakat, tanggapan oleh informan I.4 sebagai berikut:

"itu hasil pengadaan lama, jadi barang sudah diserahkan tapi dokumen penyerahannya tidak ada. Pengurus barang yang baru tidak megang dokumennya jadi masih tercatat di KIB."

"kami sedang melakukan penelusuran, sedang dibuatkan BAST hibahnya dan ketetapan kepala daerahnya, namun karena jumlahnya banyak jadi masih dicicil pengerjaannya."

Permasalahan mengenai proses Pemindahtanganan yang tidak sesuai dengan ketentuan Permendagri Nomor 19/2016 dan berpengaruh terhadap pengelolaan BMD seperti yang tercantum dalam Laporan Hasil Pemeriksaan BPK RI antara lain:

Barang yang dimaksudkan untuk diserahkan kepada masyarakat atau pihak ketiga maupun barang yang telah diserahkan ke masyarakat atau pihak ketiga masih dicatat dalam KIB. Pengurus Barang OPD terkait tidak dapat menunjukkan keseluruhan dokumen BAST Hibah, Naskah Hibah, dan permohonan penghapusan barang.

\subsubsection{Penatausahaan}

Penatausahaan BMD adalah rangkaian kegiatan yang meliputi pembukuan, inventarisasi, dan pelaporan BMD sesuai dengan ketentuan peraturan perundangundangan. Dalam penatausahaan BMD, Pengguna Barang/Kuasa Pengguna Barang berwenang dan bertanggungjawab dalam melakukan pendaftaran dan pencatatan BMD ke dalam Daftar Barang Pengguna (DBP)/Daftar Barang Kuasa Pengguna (DBKP) menurut kodefikasi barang. Pencatatan BMD dimaksud, dimuat dalam Kartu Inventaris Barang (KIB).

Proses penatausahaan BMD pada Pemda dilaksanakan dengan menggunakan program aplikasi. Pengguna Barang melalui Pengurus Barang mencatat mutasi BMD dalam KIB, untuk disajikan dalam Laporan Tahunan.

Pengelola Barang dan Pengguna Barang diharuskan melaksanakan sensus BMD setiap lima tahun sekali untuk menyusun Buku Inventaris dan Buku Induk Inventaris beserta rekapitulasi barang milik pemerintah daerah. Pengguna/Kuasa Pengguna Barang menyusun laporan barang semesteran dan tahunan dan disampaikan kepada Kepala Daerah melalui Pengelola BMD.

Informasi yang diperoleh dalam wawancara sebagai berikut: 
"untuk penatausahaan kami menggunakan aplikasi dari vendor, masing-masing OPD menginput ke daftar barang, baru kemudian kami menghimpunnya. Kalau inventarisasi fisik terakhir kami melakukannya di Tahun 2015."

Permasalahan mengenai proses Penatausahaan yang tidak sesuai dengan ketentuan

Permendagri Nomor 19/2016 dan berpengaruh terhadap pengelolaan BMD seperti yang tercantum dalam Laporan Hasil Pemeriksaan BPK RI antara lain:

1. Pemda belum mencatat atas aset tanah di bawah ruas jalan;

2. Aset Tetap Peralatan dan Mesin dicatat secara global dalam KIB. Aset-aset yang dicatat secara global tersebut berdampak pada kewajaran penyajian saldo aset di Neraca mengingat dalam satu kontrak pengadaan yang dicatat dalam satu aset tidak semua akan masuk ke dalam Neraca ada pula aset-aset dengan nilai perolehan di bawah batas kapitalisasi yang semestinya dikeluarkan dari pencatatan di Neraca.

3. Aset Tetap Gedung dan Bangunan dicatat dalam KIB C sesuai nama paket pengadaan dan belum dirinci sesuai klasifikasi jenis asetnya. Dalam permasalahan tersebut disebutkan bahwa aset yang tercatat dalam KIB C adalah satu paket pekerjaan padahal di dalam paket tersebut berisi meubelair/perabotan yang seharusnya dicatat dalam KIB B. Kondisi ini akan berakibat pada perhitungan nilai beban penyusutan dan akumulasi penyusutan karena umur manfaat dari masing-masing aset berbeda.

4. Terdapat pekerjaan pembangunan bertahap bangunan, renovasi, rehabilitasi, peningkatan jalan dan jasa konsultansi gedung dan bangunan yang belum dikapitalisasi atau masih tercatat terpisah dengan aset induk. Kondisi ini akan berakibat pada perhitungan nilai beban penyusutan dan akumulasi penyusutan karena pekerjaan tersebut akan dihitung sebagai aset yang berbeda. Seharusnya pekerjaan-pekerjaan tersebut pencatatannya digabung dengan aset induk sehingga akan menambah masa manfaat dari aset induk.

Permasalahan pada penatausahaan menjadi pengecualian dari pemberian opini oleh BPK RI, karena kondisi yang disebutkan diatas berakibat penyajian angka yang tidak wajar, tidak hanya pada akun aset tetap tapi juga pada akun akumulasi penyusutan serta akun beban penyusutan.

\subsubsection{Pembinaan, Pengawasan dan Pengendalian}

Pengguna Barang melakukan pemantauan dan penertiban terhadap penggunaan, pemanfaatan, pemindahtanganan, penatausahaan, pemeliharaan, dan pengamanan BMD yang berada di bawah penguasaannya. Pengguna dan Kuasa Pengguna Barang dapat meminta aparat pengawas fungsional untuk melakukan audit tindak lanjut hasil pemantauan dan penertiban. Pengelola berwenang untuk melakukan pemantauan dan investigasi atas pelaksanaan penggunaan, pemanfaatan, dan pemindahtanganan BMD, dalam rangka penertiban penggunaan, pemanfaatan, dan pemindahtanganan BMD sesuai ketentuan yang berlaku.

Penjelasan dari masing-masing pemda dapat disimpulkan bahwa belum ada audit khusus tindak lanjut hasil pemantauan dan penertiban dari aparat pengawas fungsional dhi. Inspektorat Kabupaten. Kondisi ini seperti diutarakan oleh informan I.2 berikut:

"kalau untuk pemeriksaan khusus pengelolaan BMD tidak pernah. Inspektorat hanya melakukan audit reguler yang biasanya juga memeriksa aset tetapi tidak keseluruhan."

\subsection{Penyebab Permasalahan Pengelolaan Barang Milik Daerah}




\section{a. Sumber Daya Manusia}

Kegiatan pengelolaan Barang Milik Daerah dengan segala ukuran keberhasilan dan dampak positif serta negatifnya tidak terlepas dari kontribusi sumber daya manusia yang kompeten. Sumber daya manusia dalam hal ini merupakan personil yang ditugaskan untuk melakukan pengelolaan BMD, yaitu Bidang Aset Daerah serta masing-masing pengurus barang OPD. Permasalahan pada sumber daya manusia, tidak hanya bersifat kompetensi, namun juga kuantitasnya. Terutama untuk OPD yang mengelola banyak UPT seperti Dinas Pendidikan dan Dinas Kesehatan.

Keterbatasan pemahaman pengurus barang serta pengurus barang pembantu dalam menjalankan fungsi dan peranannya menyebabkan adanya aset tetap yang tidak dapat ditelusuri keberadaannya. Permasalahan lain mengenai masalah SDM adalah masih ada pengurus barang yang belum memahami pengelolaan berbasis aplikasi berimplikasi pada proses pengentrian data aset tetap secara tidak cermat dan tidak tepat dilakukan oleh pengurus barang pada format yang tersedia pada aplikasi SIMDA tersebut.

Kepedulian dari pengurus barang terhadap tugasnya mengakibatkan seringnya pengurus barang yang seakan melepas tanggung jawab. Kesalahan-kesalahan pengurus barang sebelumnya yang tidak cermat melakukan pencatatan pada masa lalu sehingga rincian identitas aset tetap daerah yang diperoleh dan masuk dalam neraca daerah tidak informatif mengakibatkan kejanggalan bagi pengguna laporan BMD seperti oleh auditor Badan Pemeriksa Keuangan.

Masalah lainnya yang dapat menyebakan kendala pengelolaan BMD adalah pergantian pengurus barang. Pergantian pengurus barang kadang dilakukan tanpa pertimbangan dan prosedur yang tepat. Pergantian pengurus barang yang lama dengan pengurus barang yang baru tidak berjalan dengan baik, artinya tidak dilengkapi dengan berita acara serah terima meliputi data BMD dan dokumen pendukung BMD tentu akan menimbulkan kendala baru bagi pengurus barang yang baru diantaranya pengurus barang harus mencari informasi terkait dengan dokumen ataupun perolehan BMD ke pengurus barang lama.

Permasalahan terakhir dari sisi SDM yang ditangkap oleh peneliti adalah masalah kelebihan beban kerja. Kompleksnya rincian tugas pengurus barang dalam melaksanakan tugasnya pada pengelolaan aset tetap mulai dari mencatat barang perolehan, mengentri barang sesuai jenis dan klasifikasinya, hingga melakukan tugas lainnya diluar jabatannya sebagai pengurus barang membuat pengurus barang tidak fokus terhadap tugas dan kewajibannya dalam menginventarisasi aset tetap di Pemerintah Daerah dan berimbas terhadap kualitas laporan BMD yang dihasilkan. Hal ini terjadi terutama pada OPD yang memiliki jumlah dan nilai aset yang besar. Informasi tambahan mengenai kelebihan beban kerja adalah bahwa pengurus barang tidak hanya bertanggung jawab atas pengadaan BMD pada tahun berjalan saja, tetapi BMD perolehan terdahulu juga.

b. Kurangnya Koordinasi

Koordinasi menjadi bagian penting diantara unsur dan unit yang ada pada Pemerintah Daerah untuk mewujudkan tujuannya dalam kegiatan inventarisasi barang milik daerah dimana dalam melaksanakan tugasnya unsur-unsur dan unit-unit ini saling bergantung. Proses inventarisasi BMD dan penyelesaian tindak lanjut rekomendasi temuan hasil pemeriksaan BPK merupakan kegiatan yang membutuhkan koordinasi antara pengurus barang yang menjadi ujung tombak dalam kegiatan tersebut dengan aparatur lainnya mulai dari koordinasi pada perencanaan, perolehan, penyimpanan hingga informasi lain yang dapat mendukung jalannya pelaksanaan inventarisasi BMD. 
Ketika terjadi penerimaan hibah barang milik pada sekolah, pejabat yang menerima bantuan hibah tersebut tidak menginformasikan ke pengurus barang OPD bahwa ada aset tetap yang baru dan harus dilakukan pencatatan terhadap aset tersebut oleh pengurus barang. Adanya aset tetap tersebut justru diketahui oleh pengurus barang ketika menjadi temuan dalam pelaksanaan audit terhadap terhadap OPD tersebut.

Koordinasi dalam penyimpanan dokumen perolehan aset tetap. Sebagaimana didapatkan informasi dari beberapa informan dalam penelitian ini bahwa dokumen yang menjadi dasar dalam melakukan pencatatan terhadap aset tersebut seringkali menjadi penghambat dalam pelaksanaan tugas pengurus barang. Pengadaan aset yang tidak dikoordinasikan dengan pengurus barang juga berlanjut pada penyimpanan dokumen perolehan aset yang seringkali dilakukan penyimpanan oleh sub bagian keuangan pada masing-masing dinas.

Permasalahan lainnya akibat kurang koordinasi adalah tidak adanya pengawasan baik terhadap pencatatan atau fisik BMD itu sendiri oleh Bidang Aset ataupun aparat pengawas di Pemda. Permasalahan mengenai lemahnya koordinasi ini dapat teratasi salah satunya yaitu komitmen dari Kepala Daerah dan juga Sekretaris Daerah selaku pengelola barang yang kuat untuk membenahi permasalahan di Bidang Aset. Rekomendasi oleh BPK atas temuan mengenai permasalahan aset merupakan jalan untuk perbaikan pengelolaan BMD. Hal ini diungkapkan oleh Kepala Bidang Aset sebagai berikut:

"secara umum saran-saran dari BPK itu merupakan solusi untuk permasalahan aset. Jadi bagaimana Pemda menindaklanjutinya itu merupakan langkah penting dalam penyelesaian aset di (Kabupaten) Sambas.

"Terhadap hasil audit (Temuan), Pemerintah Kabupaten Sambas membenahi seluruh permasalahan yang memprioritaskan materialitas permasalahan. Perbaikan yang dilakukan dengan mengerahkan seluruh sumber daya dinilai sejalan dengan hasil opini yang diperoleh."

c. Inventarisasi yang belum memadai

Kegiatan inventarisasi yang dilaksanakan secara khusus dan menyeluruh bertujuan untuk mengakuratkan pelaksanaan pencatatan semua barang milik daerah serta barang inventaris milik negara yang digunakan/dikuasai oleh Pemerintah Kabupaten dengan cara pencocokan data yang tersedia dengan kondisi lapangan dan pencatatan langsung terhadap barang-barang yang belum tercatat, serta melakukan verifikasi sehingga diperoleh data yang lengkap dan terinci sesuai dengan kenyataan yang sebenarnya.

Permendagri Nomor 19 Tahun 2016 menyebutkan bahwa "Pengguna Barang melakukan inventarisasi barang milik daerah paling sedikit 1 (satu) kali dalam 5 (lima) tahun." Hasil wawancara diketahui di Pemda Sambas dan Pemda Kayong Utara terakhir kali melakukan sensus barang pada Tahun 2015, sementara Pemkab Bengkayang terakhir kali melakukan sensus barang pada Tahun 2007. Namun masih ditemukan banyak permasalahan mengenai pengelolaan BMD seperti yang tertuang dalam laporan hasil pemeriksaan BPK.

Pada laporan hasil pemeriksaan BPK selalu terdapat rekomendasi berupa inventarisasi, verifikasi maupun validasi, baik secara fisik maupun dokumentasi. Namun atas rekomendasi tersebut tidak langsung dilakukan tindak lanjut secara keseluruhan. Hal ini seperti diungkapkan oleh informan I.4 sebagai berikut:

"kami sudah berupaya menindaklanjuti rekomendasi BPK berupa inventarisasi, verifikasi maupun validasi, namun kami akui memang belum maksimal. Banyak kendala yang kami 
hadapi, misalnya dokumentasi yang tidak lengkap jadinya sulit buat melacak keberadaan barang. Secara personil juga kurang, mereka juga mengerjakan tugas lain selain mengurus BMD."

Permasalahan ini ditanggapi oleh I.3. sebagai berikut:

"tentunya saya sebagai pengelola barang selalu mendorong untuk pengurus barang menginventarir barang serta dokumen-dokumen yang lama-lama. Namun rasa tanggung jawab dari masing-masing pengurus barang yang menurut saya masih kurang, jadi kami belum optimal dalam membenahi masalah aset ini."

d. Pendokumentasian yang belum memadai

Selanjutnya yang menjadi permasalahan menurut peneliti adalah masalah pendokumentasian yang belum memadai. Hal ini disimpulkan karena banyaknya temuan dalam laporan hasil pemeriksaan BPK mengenai penatausahaan aset, bahkan yang mempengaruhi pemberian opini WDP. Temuan ini merupakan akumulasi dari tahun-tahun sebelumnya sehingga nilainya semakin besar dan material. Kendala dari perbaikan atas temuan ini karena pendokumentasian yang tidak baik, sehingga sulit untuk mencarinya. Seperti yang diutarakan oleh informan berikut:

"Nah saat itu kita dikasi waktu kan untuk cari dokumennya, dokumen pengadaan SP2D, atau Dokumen kontrak yang berkaitan dengan temuan itu dah, tapi gak ketemu-ketemu, kita cari di gedung kantor lama tidak juga ketemu, padahal biasanya mereka yang simpan."

Hasil wawancara lebih lanjut diketahui bahwa pengurus barang saat ini tidak mendokumentasikan dokumen pengadaan. Pada saat penginputan, mereka memperoleh dokumen pengadaan dari bendahara ataupun dari bidang yang melakukan pengadaan barang. Setelah diinput ke aplikasi, dokumen tersebut dikembalikan lagi, tanpa di-copy untuk menjadi dokumentasi pengurus barang.

Hal tersebut mengindikasikan bahwa mereka kurang memahami secara keseluruhan tanggung jawab pengurus barang seperti yang disebutkan dalam Permendagri Nomor 19 tahun 2016 yang menyebutkan salah satu tanggung jawab pengurus barang adalah menyimpan dokumen fotokopi/salinan dokumen kepemilikan barang milik daerah dan menyimpan asli/fotokopi/salinan dokumen penatausahaan.

Penetapan pengurus barang yang dilakukan setiap tahun anggaran memungkinkan terjadinya pergantian pengurus barang setiap tahun anggaran. Seringkali pergantian pengurus barang tersebut tidak disertai dengan berita acara serah terima yang memuat data aset daerah yang akan menjadi tanggung jawab pengurus barang yang baru sehingga pengurus barang yang baru kesulitan dalam menginventarisir aset yang perolehannya bukan pada saat dia menjadi pengurus barang melainkan terjadi pada pengurus barang sebelum dia bertugas.

\section{SIMPULAN DAN SARAN}

Berdasarkan data yang diperoleh pada penelitian ini dari sumber bukti berupa dokumen, rekaman arsip dan hasil wawancara, peneliti menyimpulkan bahwa pengelolaan BMD pada tiga entitas yang menjadi sampel dalam penelitian ini belum sepenuhnya memadai sesuai dengan Permendagri Nomor 19 Tahun 2016. Hal ini dibuktikan dengan masih terdapat temuan hasil pemeriksaan BPK RI mengenai pengelolaan Aset Tetap, dimana dari aspek penatausahaan berpengaruh terhadap pemberian opini WDP oleh BPK RI. Temuan-temuan tersebut sebagian 
besar disebabkan pengelolaan pada tahun-tahun lama yang dalam tindak lanjutnya tidak diselesaikan secara memadai. Rekomendasi dari BPK RI sebenarnya telah dirumuskan untuk mengatasi permasalahan mengenai pengelolaan BMD tersebut. Namun atas rekomendasi tersebut belum diselesaikan secara memadai. Akibat dibiarkan terlalu lama sehingga dari tahun ke tahun nilai temuannya semakin besar menyebabkan pengaruh kepada pemberian opini WDP oleh BPK karena dianggap material.

Dari permasalahan pengelolaan BMD, penulis menemukan 4 (empat) tema penyebab dari penyelesaian permasalahan pengelolaan BMD, yaitu sumber daya manusia, kurangnya koordinasi, inventarisasi yang belum memadai serta pendokumentasian yang belum memadai.

Berdasarkan hasil penelitian, saran yang dapat diberikan untuk Pemerintah Kabupaten Bengkayang dan Pemerintah Kabupaten Kayong Utara khususnya yang masih belum memperoleh opini WTP serta kepada Pemerintah Kabupaten Sambas untuk tetap mempertahankan opini WTP adalah :

a. Memberikan perhatian dan motivasi kepada pengurus barang serta pegawai pada Bidang Aset agar lebih semangat dalam melaksanakan tugasnya, mempunyai disiplin, serta motivasi dan integritas yang tinggi;

b. Memberikan bimbingan dan pembinaan dalam melakukan pengelolaan BMD;

c. Menempatkan SDM yang berkompeten serta cukup secara kuantitas untuk mendukung pengelolaan BMD menjadi lebih baik;

d. Mengoptimalisasikan peranan Pengawas Internal (Inspektorat Kabupaten) terhadap penyelesaian permasalahan pengelolaan BMD.

\section{REFERENCES}

Akbar, R., dan Lukman, A., 2010. Manajemen Taman Milik Pemerintah Kota Bandung Berbasiskan Pendekatan Manajemen Aset. Jurnal Teoritis dan Terapan Bidang Rekayasa Sipil. Jurnal Teoretis dan Terapan Bidang Rekayasa Sipil.

Freeman, Robert J. dan Craig D. Shoulders (2003). Governmental and Nonprofit AccountingTheory and Practice. Seventh edition. Upper Saddle River, NJ: Prentice Hall.

Gunawan, I (2013, Metode Penelitian Kualitatif. Jakarta: Bumi Aksara.

Mulyani E, Rachmina D, Kusnadi N. (2016). Strategi Pengelolaan Aset Tetap Pada Pemerintah Provinsi Banten. Jurnal Manajemen Pembangunan Daerah, 8, 42-55.

Republik Indonesia (2004). Undang Nomor 15 Tahun 2004 tentang Pemeriksaan Pengelolaan dan Tanggung Jawab Keuangan Negara. Jakarta : Sekretariat Negara.

Republik Indonesia (2005). Pernyataan Standar Akuntansi Pemerintahan (SPAP) No. 07 tentang Akuntansi Aset Tetap. Jakarta : Sekretariat Negara.

Republik Indonesia (2010). Peraturan Pemerintah (PP) Nomor 71 Tahun 2010 tentang Standar Akuntansi Pemerintah. Jakarta : Kementerian Hukum dan HAM RI.

Republik Indonesia (2014). Peraturan Pemerintah (PP) No. 27 Tahun 2014 tentang Pengelolaan Barang Milik Negara/Daerah. Jakarta : Kementerian Hukum dan HAM RI.

Republik Indonesia (2016). Peraturan Menteri Dalam Negeri (Permendagri) No. 19 Tahun 2016 tentang Pedoman Pengelolaan Barang Milik Daerah. Jakarta : Kementerian Dalam Negeri. 
Republik Indonesia (2018). Ikhtisar Hasil Pemeriksaan Semester (IHPS) Semester I Tahun 2018 BPK RI. Jakarta : Badan Pemeriksa Keuangan Republik Indonesia.

Sholeh, C. Rochmansjah, H. (2010), Pengelolaan Keuangan dan Aset Daerah Sebuah Pendekatan Struktural Menuju Tata Kelola Pemerintahan Yang Baik. Bandung: Fokusmedia.

Surminah, L, (2008). "Manajemen Aset di Lembaga Litbang", Warta Kebijakan Iptek \& Manajemen Litbang, penerbit Papiptek-LIPI, Jakarta, 2008:77-94.

Syahputra, K. Syaukat, Y. Irwanto, AK. (2018). Strategi Peningkatan Pengelolaan Barang Milik Daerah pada Pemerintah Kabupaten Kepulauan Anambas. Jurnal Manajemen Pembangunan Daerah, 10, 1-14.

Tanjung, A. H. (2012). Akuntansi Pemerintah Daerah Berbasis Akrual. Bandung: Alfabeta. 